Article

\title{
Investigating Critical Non-Value Adding Activities and Their Resulting Wastes in BIM-Based Project Delivery
}

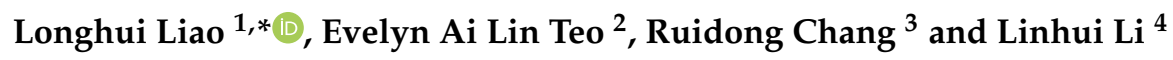 \\ 1 Sino-Australia Joint Research Center in BIM and Smart Construction, Shenzhen University, \\ Shenzhen 518060, China \\ 2 Department of Building, School of Design and Environment, National University of Singapore, \\ Singapore 117566, Singapore; bdgteoal@nus.edu.sg \\ 3 School of Architecture and Built Environment, The University of Adelaide, North Terrace, \\ Adelaide 5005, Australia; ruidong1231@gmail.com \\ 4 Bank of China Limited Singapore Branch, Singapore 049908, Singapore; lilinhui131@pingan.com.cn \\ * Correspondence: liao.longhui@szu.edu.cn
}

Received: 26 September 2019; Accepted: 16 December 2019; Published: 2 January 2020

\begin{abstract}
Building information modeling (BIM) is deemed a useful innovation for technological and sustainable development of the economy. It is partially used in building projects in Singapore, although its implementation is mandated by the local government, resulting in various wastes and suboptimal productivity. Little is known about how non-value adding (NVA) BIM implementation practices were perceived by the local practitioners and how these practices affected productivity in building projects in Singapore. This study aimed to identify critical NVA BIM implementation activities and investigate the criticality of their resulting wastes to productivity performance in the current project delivery process in Singapore. The results from a questionnaire survey of 73 experts and four post-survey interviews in Singapore revealed that 38 NVA BIM implementation activities were deemed critical, among which "lack of involvement by contractors to contribute site knowledge" in the design development phase was ranked top; the top five resulting wastes with highest criticalities were reworks/abortive works, requests for information, design deficiencies, defects, and waiting/idle time. Furthermore, an independent-samples $t$-test was conducted to examine whether construction firms and upfront stakeholders perceived the NVA activities differently. It was discovered that most NVA activities exerted more agreement from construction firms than upfront non-construction organizations. Six strategies were proposed to mitigate the NVA activities and wastes. The findings can help practitioners identify weak areas of their BIM implementation practices and prioritize resources accordingly to eliminate the wastes and foster sustainability, as well as help overseas project teams, with minor adjustments, customize their own NVA BIM implementation activities and management strategies.
\end{abstract}

Keywords: non-value adding; waste; building information modeling (BIM); implementation; project lifecycle; sustainability; productivity; construction firm

\section{Introduction}

Owing to increasing greenhouse gas (GHG) emissions, climate change could consume at least $5 \%$ of the global gross domestic product (GDP) [1]. The construction industry is not only one of the largest sources of GHG emissions [2,3], but also a large contributor to the GDP in the world economy. This contribution to the GDP ranges from $7 \%$ to $10 \%$ in developed countries and $3 \%$ to $6 \%$ in developing countries [4]. In order for the economy to stay competitive and sustainable, the construction industry 
or GDP growth at large should be driven by productivity. Building information modeling (BIM) was found to be useful in improving productivity $[5,6]$. Nevertheless, changing toward full adoption of BIM was generally slow due to entrenching in traditional project delivery $[7,8]$ and adopting a wait-and-see attitude [9].

This trend of adopting BIM was also seen in Singapore. The local government is dominant in promoting BIM [9,10]. In 2010, Singapore's Economic Strategies Committee (ESC) [11] set a target to achieve productivity growth of $2 \%$ to $3 \%$ per year in the 2010s. The growth is measured by value added per employee. To meet this target, the first Construction Productivity Roadmap was formulated in 2010 to transform the construction industry, among which the most important legislation was a five-year BIM adoption roadmap. Specifically, the Building and Construction Authority (BCA) mandated that all new building projects (both private and public) with gross floor areas (GFAs) of greater than 20,000 $\mathrm{m}^{2}$ must submit their architectural plans in BIM format for regulatory approvals since July 2013 and submit their structural and mechanical, electrical, and plumbing (MEP) plans in BIM format since July 2014. Now, all new building projects with GFAs of $5000 \mathrm{~m}^{2}$ and above have to make architectural, structural, and MEP submissions in BIM format since July 2015 [12]. In addition, the BCA drives the local construction value chain to work collaboratively, with part of its implementation cost being subsidized [13]. Thus, the Singapore government's mandate and keenness on BIM has changed the lifecycle process of delivering almost all private and public building projects [14]. However, the Singapore Department of Statistics (SDOS) [15] reported that productivity growth in the construction industry was $2.2 \%$ (2011), $2.7 \%$ (2012), $-6.1 \%$ (2013), $1.9 \%$ (2014), $4.0 \%$ (2015), $1.4 \%$ (2016), and $-1.8 \%$ (2017), failing to meet the target from 2013 to 2017, overall, when BIM submissions became mandatory.

This was because the local industry practitioners may not adequately understand how to implant BIM work practices into the project lifecycle, and they could not adapt to the new project delivery process [16,17]. Lam [18] reported that BIM implementation tended to be fragmented in individual parties, rather than based on project-wide collaboration. Both physical and information fragmentation existed across the planning, design, construction, and operations stages [14]. The local BIM experts reported that the BIM mandate itself might be wasteful because the submittals prepared in the design phase were at a higher level of detail and precision and could not be reusable in the later stages of a project [14]. Consequently, contractors very often used the traditional computer-aided design (CAD) drafting practices. The hybrid of BIM and CAD practices in the same project consumed extra time and resources.

Thus, many non-value adding (NVA) BIM implementation activities exist in the current industry practices in Singapore, creating wastes (such as time wasted in requesting and waiting for clarification), which seriously affects productivity. All production consists of wastes and work. Wastes include needless repetitive movement (such as waiting for subassemblies). Work includes both value-adding work and NVA work (such as walking to pick up materials) that have to be done under present working conditions [19]. In this study, NVA BIM implementation activities refer to those that have to be done under the current project delivery process but do not add value in an ideal BIM-based project delivery. Having a good knowledge of the NVA activities helps change more purposively. Juan et al. [9] studied how to incorporate BIM to change NVA practices in the building review process in Taiwan, but this previous study only considered architectural consultancy firms in the design stage. Thus, understanding NVA BIM implementation activities in the project lifecycle and the perceptions of different project stakeholders on such activities requires much investigation.

The objectives of this study were to (1) identify the critical NVA BIM implementation activities in the current building project delivery in Singapore, (2) compare the agreement of these NVA activities between non-construction organizations upfront and construction firms, (3) investigate the criticality of the wastes resulting from the NVA activities to productivity performance, and (4) provide strategies to mitigate the NVA activities and wastes. The ESC advocated that the labor-intensive industry should improve work efficiencies to maintain competitiveness and sustainability. Thus, the lifecycle BIM implementation activities in building projects have a critical implication. Although there were 
studies $[3,20]$ focusing on how to enhance BIM implementation and reduce wastes for promoting sustainability, few attempted to investigate the NVA BIM implementation activities and their resulting wastes. This study is the first to investigate the critical NVA activities' influence on productivity performance via their resulting wastes. Now that the BIM submissions in new private and public building projects are mandatory, the industry practitioners have to change their work practices. This study also analyzes similarities and differences in stakeholder groups' perceptions regarding the critical NVA BIM implementation activities. While BIM technology itself is advanced and ready, project-wide collaboration is the basic premise of successful BIM-based project delivery, as recommended by the National Institute of Building Sciences (NIBS) [21]. To move from the current, partial BIM-based delivery toward a more collaborative one, it is significant for the local firms to cut down their NVA BIM implementation activities, especially during the design and design-construction interface stages. Nonetheless, without clear guidance, the firms may not know how to collaborate with others [22]. They tend to be unwilling to change their customized ways of working, unless they are pushed by the government [23] or their competitors are already implementing BIM [9]. In addition, the critical NVA activities in BIM-based delivery serves as a benchmark, with which the practitioners can compare their BIM implementation practices, allowing them to wisely allocate their limited resources to the NVA activities worth more attention to reduce the wastes. Thus, this study can contribute to the literature related to BIM implementation. This study focuses on the previously established relationship between negative or slow productivity growth and existing critical NVA BIM implementation activities, whereas other issues contributing to the suboptimal productivity are beyond the scope.

\section{Background}

\subsection{BIM-Based Project Delivery in the Singapore Construction Industry}

Building projects in Singapore are currently implementing BIM partially. Specifically, the local industry is facing many issues; owners may lack relevant knowledge and are unable to see beyond initial costs, design consultants may focus too much on the mandatory submissions and have little time and inadequate fees to perform design coordination for downstream parties, general contractors have to re-build design models as the consultants may not share their models and such models were not created in the way the contractors would have built the buildings, and operations and maintenance teams are rarely involved during the design and planning phase $[17,18,24]$. Without knowing downstream BIM uses in a building project, the design team may not be able to identify reusable project information and important information exchanges [25], creating various wastes in the later stages of this project.

\subsection{NVA BIM Implementation Activities in Project Delivery}

The partial BIM adoption created major NVA BIM implementation practices in the current project delivery process in Singapore. Such practices result in various wastes and consume workers' time and other resources, and they do not add value to the delivery process and final buildings [26-28].

It should be clarified that the findings presented in this current paper form phase II of a much larger research project. Because of the word limit, this paper could only present the NVA BIM implementation activities and their resulting wastes in building project delivery in Singapore. In phase I of the research project, Liao et al. [14] analyzed key BIM implementation activities in the current, partial BIM-based delivery and compared them with their counterparts in an integrated project delivery (IPD) in terms of project phasing and major stakeholders (not presented here). The IPD has materialized as an approach that can most effectively and fully facilitate BIM implementation in building projects, according to Porwal and Hewage [7], the American Institute of Architects, California Council (AIACC) [29], and Piroozfar et al. [30]. The major NVA practices were generated from the comparison, with support from a literature review $[7,18,25,29,31-37]$. For this phase II, these NVA practices were translated into 44 common NVA activities spanning from project beginning to the operations and maintenance phase. For instance, in a typical building project, agreements were usually made between two parties (rather 
than amongst the entire team) and, thus, restricted information (such as not sharing BIM models), downstream stakeholders were rarely involved upfront to contribute their site and manufacturing knowledge in design, the primary parties excelled in risk transfer by contracts and liability assessment but did little to avoid risks, and the project was usually controlled by the owner and architect instead of by a core team involving key engineers and contractors. Detailed descriptions of these activities are presented in Section 4. A project leadership team can understand its BIM implementation readiness by comparing its planned BIM implementation activities with the NVA activities identified above. The more NVA activities occur or such activities occur more frequently, the lower the BIM implementation readiness would be.

\subsection{Resulting Wastes of NVA Activities}

NVA work held a considerable portion in most construction processes and in some cases even exceeded $50 \%$ of the total work, leading to productivity loss [38]. Productivity improvement could be achieved through diagnosing and cutting down the critical NVA activities, because fewer NVA activities would create fewer wastes, such as reworks, waiting time, and requests for information (RFIs), and they would need fewer employees and/or less time to complete a project. For example, currently, if the contractors use poorly coordinated and unclear building plans to install air-conditioning systems on site, they would raise tremendous RFIs. This causes field conflicts, compels site staff to wait for the consultants' responses, and requires reworks, affecting productivity. However, with full BIM use and early involvement of the downstream parties, all building systems can be defined, coordinated, and engineered during the design stage [39]. These RFIs would occur earlier and informally before the field staff worked with an imperfect plan. This means fewer conflicts and less confusion during construction, improving productivity [40].

In this study, to evaluate the critical NVA activities' impact on productivity, a total of 13 wastes resulted from these activities were identified from 19 previous studies in the literature review (see Table 1). For instance, Nikakhtar et al. [28] categorized noticeable wastes (such as overproduction, unnecessary inventory, transporting, and waiting time) hidden in construction processes due to the nature of operations and NVA work, and studied how they could be reduced by adopting lean thinking. Saieg et al. [41] found that synergies between BIM and lean thinking for reducing the wastes and fostering sustainability were mainly in the conceptual design phase and the construction phase. However, none of these previous studies explored the wastes derived from the lifecycle NVA BIM implementation activities in the Singapore context. Thus, this study contributes to the literature related to waste reduction and BIM implementation.

Table 1. Potential wastes affecting productivity more seriously.

\begin{tabular}{|c|c|c|c|c|c|c|c|c|c|c|c|c|c|c|c|c|c|c|c|c|}
\hline \multirow{2}{*}{ Code } & \multirow{2}{*}{ Resulting Waste } & \multicolumn{19}{|c|}{ References } \\
\hline & & [42] & [43] & [44] & [45] & [46] & [47] & [48] & [49] & [50] & [51] & [52] & [5] & [28] & [19] & [53] & [54] & [55] & [56] & [26] \\
\hline W01 & Defects & $\mathrm{x}$ & & $\mathrm{x}$ & $\mathrm{x}$ & & & & & & $\mathrm{x}$ & $\mathrm{x}$ & & $\mathrm{x}$ & $\mathrm{x}$ & $\mathrm{x}$ & & & $\mathrm{x}$ & \\
\hline W02 & Requests for information & & $\mathrm{x}$ & $\mathrm{x}$ & & & & & $\mathrm{x}$ & & & & $\mathrm{x}$ & $\mathrm{x}$ & & $\mathrm{x}$ & & & & \\
\hline W03 & Reworks/abortive works & & $x$ & & & $\mathrm{x}$ & $\mathrm{x}$ & & $x$ & & & & $\mathrm{x}$ & $x$ & & $x$ & & $\mathrm{x}$ & & \\
\hline W04 & Waiting/idle time & $\mathrm{x}$ & $\mathrm{x}$ & $\mathrm{x}$ & $\mathrm{x}$ & & & & & $\mathrm{x}$ & & $x$ & & $\mathrm{x}$ & $x$ & $\mathrm{x}$ & & & & \\
\hline W05 & Change orders & & & & & & $\mathrm{x}$ & & $\mathrm{x}$ & & & & & & & & & $\mathrm{x}$ & & \\
\hline W06 & Activity delays & & $\mathrm{x}$ & $\mathrm{x}$ & & & & & & & & & & $\mathrm{x}$ & & $\mathrm{x}$ & & & & $\mathrm{x}$ \\
\hline W07 & Overproduction/reproduction & $\mathrm{x}$ & $\mathrm{x}$ & $\mathrm{x}$ & $\mathrm{x}$ & $\mathrm{x}$ & & $\mathrm{x}$ & & & & $\mathrm{x}$ & & $\mathrm{x}$ & $\mathrm{x}$ & $\mathrm{x}$ & & & & $\mathrm{x}$ \\
\hline W08 & $\begin{array}{c}\text { Transporting/handling } \\
\text { materials }\end{array}$ & $\mathrm{x}$ & & & $\mathrm{x}$ & & & & & $\mathrm{x}$ & & & & $\mathrm{x}$ & $\mathrm{x}$ & $\mathrm{x}$ & & & $\mathrm{x}$ & $\mathrm{x}$ \\
\hline W09 & Unnecessary inventory & $\mathrm{x}$ & & $\mathrm{x}$ & $\mathrm{x}$ & & & & & $x$ & & $\mathrm{x}$ & & $\mathrm{x}$ & $x$ & & & & $\mathrm{x}$ & \\
\hline W10 & $\begin{array}{l}\text { Excess processing beyond } \\
\text { standard }\end{array}$ & & $\mathrm{x}$ & & $\mathrm{x}$ & & & $\mathrm{x}$ & & & & $\mathrm{x}$ & $\mathrm{x}$ & & $\mathrm{x}$ & & & & & \\
\hline W11 & $\begin{array}{l}\text { Unnecessary movement of } \\
\text { people and equipment }\end{array}$ & & $\mathrm{x}$ & $\mathrm{x}$ & $\mathrm{x}$ & & & $\mathrm{x}$ & & & & & & & $\mathrm{x}$ & & & & $\mathrm{x}$ & \\
\hline W12 & $\begin{array}{l}\text { Design deficiencies (errors, } \\
\text { omissions, additions) }\end{array}$ & & $\mathrm{x}$ & & & & & & & & & & $\mathrm{x}$ & $\mathrm{x}$ & & $\mathrm{x}$ & & $\mathrm{x}$ & & \\
\hline W13 & Safety issues (injuries) & & & $\mathrm{x}$ & & & & & & & $\mathrm{x}$ & & & & & $\mathrm{x}$ & $\mathrm{x}$ & & $\mathrm{x}$ & \\
\hline
\end{tabular}


Among these wastes, defects, waiting/idle time, overproduction, transporting materials, unnecessary inventory, excess processing beyond standard, and unnecessary movement of people and equipment were the wastes that stemmed from the Toyota production system [19], while the remainder were raised by previous construction management studies. It should be noted that some similar wastes were combined, such as waiting time and idle time.

\section{Methods}

Figure 1 presents the methods adopted in this study. Since the NVA activities were collected from the literature, the level of agreement on these activities being NVA in the Singapore construction industry needed to be investigated. Similarly, the criticality of the resulting wastes should be examined. As a systematic method of collecting data based on a sample, the questionnaire survey technique was widely used to collect professional views on critical factors in previous project management studies $[17,57]$. Thus, a questionnaire survey was conducted to collect the data related to the NVA activities and their resulting wastes in building projects that used BIM in Singapore. The questionnaire, illustrated in the Supplementary Materials, was designed with support from the literature review and refined based on the comments from five BIM experts who were interviewed face-to-face in a pilot study. All the experts had more than three years of BIM implementation experience in building projects in Singapore. Three of them were a project manager, corporate BIM manager, and technical manager of large construction and development firms, with over 10 years' experience in this field; the other two included one quantity surveyor in charge of a general construction firm and one senior architectural associate from a large architectural consultancy firm, with over five years of work experience. New NVA activities were added, and the statements of all the NVA activities and their resulting wastes were revised for better readability and accuracy. The final questionnaire collected the general information of respondents, and requested them to rate the level of agreement on the activities being NVA according to one of their past or ongoing building projects, using a five-point Likert scale ( 1 = strongly disagree, $2=$ disagree, $3=$ unsure, $4=$ agree, and $5=$ strongly agree). This Likert scale system is deemed effective in measuring the respondents' attitudes [58]. Moreover, the frequency of occurrence and impact on productivity of the resulting wastes in the same project were rated using a scale for the frequency of occurrence ( $1=$ never, $2=$ rarely, $3=$ sometimes, $4=$ often, and $5=$ always $)$ and a scale for the impact on productivity $(1=$ insignificant effect, $2=$ minor detrimental effect, $3=$ moderate detrimental effect, $4=$ significant detrimental effect, and $5=$ catastrophic effect), which were also used in previous studies $[26,27,59]$. The number of objects a human can hold in working memory is "seven plus or minus two" [60]. In a one-dimensional absolute-judgment task, a person is presented with a number of stimuli and provides a response to each stimulus. Performance is nearly perfect up to five or six stimuli but declines as the number is increased. Thus, the scales of five made it convenient for the respondents to judge.

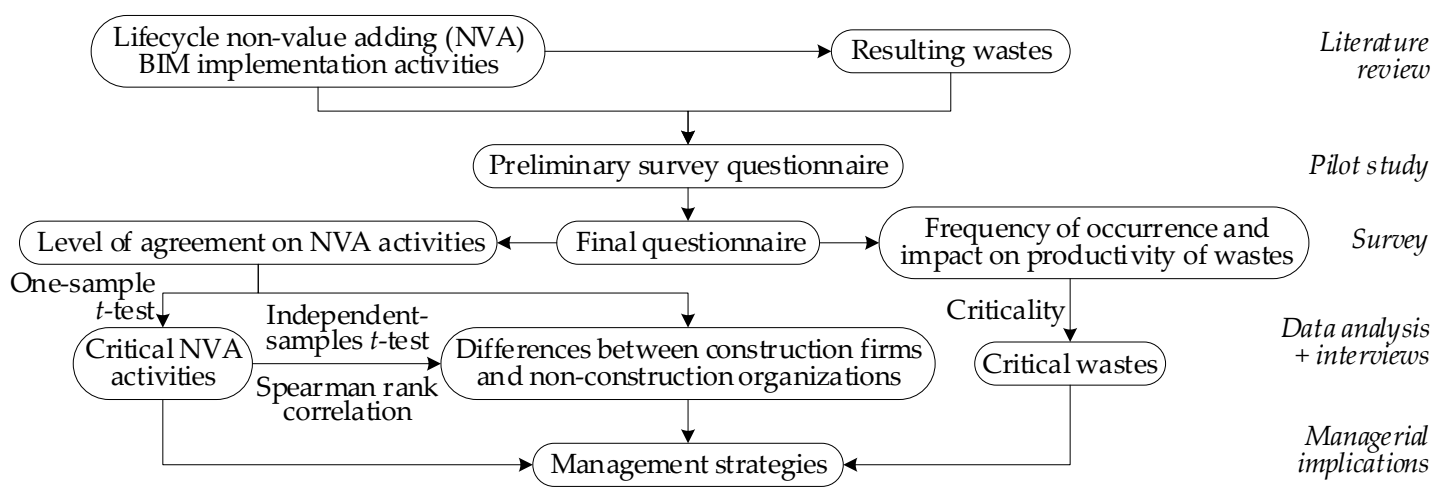

Figure 1. Research methods. 
The population comprised all the organizations in the Singapore construction industry. The sampling frame consisted of the BCA, the Urban Redevelopment Authority (URA), the Housing and Development Board, the building developers registered with the Real Estate Developers' Association of Singapore, the architectural consultancy firms registered with the Singapore Institute of Architects, the structural and MEP consultancy firms registered with the Association of Consulting Engineers Singapore, the contractors registered with the $\mathrm{BCA}$, and the facility management firms registered with the Association of Property and Facility Managers. Among the contractors, it was considered logical to select only the large ones because they had adequate resources for BIM implementation. Finally, 659 questionnaires were sent to these organizations via emails or handed to them personally, and 73 completed questionnaires were received, yielding a response rate of $11.08 \%$. This rate was acceptable because it fell within the general response rate of $10 \%-15 \%$ for Singapore surveys [61].

Table 2 presents the profile of the 73 respondents and their organizations. The 19 organizations listed in the "others" category included the BCA, the URA, developers, precasters, and other consultancy firms (such as multidisciplinary consultancy firms and a BIM consultancy firm). This indicated a good balance of the distribution of industry players and could represent the key BIM implementers in the construction value chain in Singapore. Because the building project context is a cross-enterprise environment and BIM implementation requires close collaboration and efficient communication among parties of different roles and professional backgrounds [22,30,62], heterogeneity of the responding organizations would not bias the findings of this study. Moreover, because the mandate of BIM implementation in Singapore started in July 2015 [12], it was reasonable that over half $(58.90 \%)$ of the organizations had no more than three years of experience of BIM implementation. Thus, the local construction industry is moving from the traditional delivery approach into a BIM-based delivery approach.

Moreover, post-survey interviews were conducted with four experts who participated in the aforementioned survey. All of them had over three years of experience in implementing BIM in Singapore and worked in local building projects for more than eight years. In the interviews, the experts were presented with the survey results. They commented that the findings were reasonable and in agreement with their expectations. To gain an in-depth understanding, they were also invited to explain the results, as discussed in the next section.

To measure how critical the wastes were to productivity performance in the current, partial BIM-based industry practices in Singapore, waste criticality (WC) was defined in this study. The WC of waste $i$ rated by respondent $j$ was calculated as the root square of the product of the waste's impact on productivity $(I P)$ and frequency of occurrence $(F O)$, which kept the scale of WC consistent with that of $I P$ and $F O$, as shown in Equation (1). The criticality of a factor was used in previous project management studies [57,59].

$$
W C_{i}^{j}=\sqrt{F O_{i}^{j} \times I P_{i}^{j}} .
$$

Cronbach's alpha coefficient $(\alpha)$, which should exceed 0.7 for a scale to be reliable, with 0.6 being questionable [63], was calculated to test the reliability of the 73 responses. The coefficient of the NVA activities altogether was 0.934 , indicating high data reliability. The coefficients met the requirement in all project phases, except the conceptualization phase (0.632). Nevertheless, the threshold may decrease to 0.6 for a newly developed measure in exploratory research [64]. Thus, this coefficient was acceptable. The Cronbach's alpha coefficient for the 13 wastes was 0.901 , indicating that the data were reliable. 
Table 2. Profile of respondents and their organizations. MEP—-mechanical, electrical, and plumbing; BCA—Building and Construction Authority; BIM—building information modeling.

\begin{tabular}{|c|c|c|c|}
\hline Characteristic & Categorization & $N$ & $\%$ \\
\hline \multicolumn{4}{|l|}{ Respondents } \\
\hline \multirow{9}{*}{ Discipline } & Government agent & 4 & 5.5 \\
\hline & Developer & 3 & 4.1 \\
\hline & Architect & 15 & 20.5 \\
\hline & Structural designer & 11 & 15.1 \\
\hline & MEP designer & 8 & 11.0 \\
\hline & General contractor & 19 & 26.0 \\
\hline & Subcontractor & 5 & 6.8 \\
\hline & Supplier/manufacturer & 2 & 2.7 \\
\hline & Facility manager & 6 & 8.2 \\
\hline \multirow{5}{*}{ Work experience (years) } & $5-10$ & 31 & 42.5 \\
\hline & $11-15$ & 14 & 19.2 \\
\hline & $16-20$ & 5 & 6.8 \\
\hline & $21-25$ & 4 & 5.5 \\
\hline & $>25$ & 19 & 26.0 \\
\hline \multicolumn{4}{|l|}{ Organizations } \\
\hline \multirow{7}{*}{ Main business } & Architectural firm & 11 & 15.1 \\
\hline & Structural engineering firm & 9 & 12.3 \\
\hline & MEP engineering firm & 9 & 12.3 \\
\hline & General construction firm & 23 & 31.5 \\
\hline & Trade construction firm & 1 & 1.4 \\
\hline & Facility management firm & 1 & 1.4 \\
\hline & Others & 19 & 26.0 \\
\hline \multirow{9}{*}{ BCA financial grade } & Not applicable & 36 & 49.3 \\
\hline & A1 & 22 & 30.1 \\
\hline & B1 & 2 & 2.7 \\
\hline & $\mathrm{C} 3$ & 2 & 2.7 \\
\hline & Single grade & 1 & 1.4 \\
\hline & L6 & 6 & 8.2 \\
\hline & $\mathrm{L} 4$ & 1 & 1.4 \\
\hline & $\mathrm{L} 2$ & 1 & 1.4 \\
\hline & L1 & 2 & 2.7 \\
\hline \multirow{5}{*}{ BIM adoption experience (years) } & 0 & 9 & 12.3 \\
\hline & $1-3$ & 34 & 46.6 \\
\hline & $4-5$ & 17 & 23.3 \\
\hline & $6-10$ & 11 & 15.1 \\
\hline & $>10$ & 2 & 2.7 \\
\hline
\end{tabular}

\section{Results and Discussion}

\subsection{NVA BIM Implementation Activities}

\subsubsection{Overall Values and Ranking of NVA Activities}

It should be noted that, in the NVA activities (Table 3), "architect" represented architectural consultancy firms and "engineers" represented consultancy firms of respective disciplines to reflect the Singapore context. Furthermore, for better readability, some NVA activities were presented in simple form. In addition, because this study investigated BIM implementation from the project delivery perspective, some NVA activities that seemed to be not very closely related to BIM but that fundamentally influenced BIM implementation in the delivery process were included. 
Table 3. Level of agreement ranking and $t$-test results of non-value adding (NVA) activities. RFI-request for information.

\begin{tabular}{|c|c|c|c|c|c|}
\hline Code & NVA Activities & Mean & $\begin{array}{l}\text { Overall } \\
\text { Rank }\end{array}$ & $\begin{array}{c}\text { Internal } \\
\text { Rank }\end{array}$ & $p$-Value \\
\hline \multicolumn{6}{|c|}{ Conceptualization $(\alpha=0.632)$} \\
\hline \# & Lack of involvement by government agency & 3.18 & 40 & - & 0.224 \\
\hline N1.1 & Inadequate project objectives and performance metrics set by owner & 3.51 & 25 & 3 & $0.000 *$ \\
\hline \# & Owner resists using BIM in the whole project & 2.81 & 44 & - & 0.137 \\
\hline $\mathrm{N} 1.2$ & $\begin{array}{c}\text { No reward/risk sharing arrangements among major stakeholders } \\
\text { are set by owner }\end{array}$ & 3.85 & 11 & 1 & $0.000 *$ \\
\hline N1.3 & Lack of involvement by engineers (not appointed) & 3.41 & 31 & 4 & $0.003 *$ \\
\hline N1.4 & Lack of involvement by general contractor (not appointed) & 3.73 & 17 & 2 & $0.000 *$ \\
\hline \multicolumn{6}{|c|}{ Schematic design $(\alpha=0.799)$} \\
\hline \# & Lack of involvement by government agency & 2.89 & 43 & - & 0.392 \\
\hline N2.1 & $\begin{array}{c}\text { Lack of joint control and agreement on project targets and metrics } \\
\text { by major stakeholders }\end{array}$ & 3.51 & 25 & 5 & $0.000 *$ \\
\hline $\mathrm{N} 2.2$ & $\begin{array}{l}\text { Architect, engineers, and contractors do not work together in } \\
\text { design modeling }\end{array}$ & 3.66 & 20 & 4 & $0.000 *$ \\
\hline \# & Architect does not share its complete model with engineers & 3.16 & 41 & - & 0.255 \\
\hline \# & $\begin{array}{l}\text { Architect and engineers do not submit their schematic design } \\
\text { models for regulatory approvals }\end{array}$ & 3.21 & 39 & - & 0.083 \\
\hline $\mathrm{N} 2.3$ & $\begin{array}{c}\text { Engineers not involved early in this phase to contribute in } \\
\text { architectural modeling }\end{array}$ & 3.49 & 27 & 6 & $0.001 *$ \\
\hline $\mathrm{N} 2.4$ & $\begin{array}{l}\text { Lack of involvement by general contractor and key trade } \\
\text { contractors to contribute site knowledge (not appointed) }\end{array}$ & 3.92 & 6 & 1 & $0.000 *$ \\
\hline N2.5 & $\begin{array}{l}\text { Lack of involvement by manufacturer/supplier (not appointed) to } \\
\text { contribute fabrication knowledge }\end{array}$ & 3.92 & 6 & 1 & $0.000 *$ \\
\hline N2.6 & $\begin{array}{l}\text { Lack of involvement by facility manager (not appointed) to } \\
\text { contribute operations and maintenance knowledge }\end{array}$ & 3.92 & 6 & 1 & $0.000 *$ \\
\hline \multicolumn{6}{|c|}{ Design development $(\alpha=0.772)$} \\
\hline \# & Lack of involvement by government agency & 2.93 & 42 & - & 0.567 \\
\hline N3.1 & Insufficient design review and feedback by owner & 3.26 & 38 & 8 & $0.032 *$ \\
\hline N3.2 & $\begin{array}{c}\text { Architect, engineers, and contractors do not work together in } \\
\text { design modeling }\end{array}$ & 3.56 & 22 & 5 & 0.000 * \\
\hline N3.3 & $\begin{array}{l}\text { Architect does not share its complete model with engineers and } \\
\text { contractors }\end{array}$ & 3.27 & 37 & 7 & 0.047 * \\
\hline N3.4 & $\begin{array}{l}\text { Coordination of building systems is deferred until construction } \\
\text { phase due to unavailable trade contractor input until then }\end{array}$ & 4.10 & 2 & 2 & $0.000 *$ \\
\hline N3.5 & $\begin{array}{l}\text { Lack of involvement by general contractor and key trade } \\
\text { contractors to contribute site knowledge (not appointed) }\end{array}$ & 4.21 & 1 & 1 & $0.000 *$ \\
\hline N3.6 & $\begin{array}{l}\text { Construction model is not developed due to unwillingness of } \\
\text { architect and engineers to share their BIM models }\end{array}$ & 3.30 & 36 & 6 & $0.044^{*}$ \\
\hline N3.7 & $\begin{array}{l}\text { Lack of involvement by manufacturer/supplier (not appointed) to } \\
\text { contribute knowledge of material selection, transportation, site } \\
\text { erection, and so on }\end{array}$ & 4.03 & 3 & 3 & 0.000 * \\
\hline N3.8 & $\begin{array}{l}\text { Lack of involvement by facility manager (not appointed) to } \\
\text { contribute operations and maintenance knowledge }\end{array}$ & 3.92 & 6 & 4 & $0.000 *$ \\
\hline \multicolumn{6}{|c|}{ Construction documentation $(\alpha=0.876)$} \\
\hline N4.1 & $\begin{array}{l}\text { Not fully defined and coordinated between architectural, structural, } \\
\text { and MEP design models }\end{array}$ & 3.75 & 16 & 3 & $0.000 *$ \\
\hline N4.2 & $\begin{array}{l}\text { Insufficient communication between architect and engineers } \\
\text { Information such as bill of materials, assembly, layout, detailed }\end{array}$ & 3.45 & 29 & 5 & 0.001 * \\
\hline N4.3 & $\begin{array}{l}\text { schedule, testing, and commissioning procedures is not } \\
\text { documented after design }\end{array}$ & 3.52 & 23 & 4 & $0.000 *$ \\
\hline N4.4 & $\begin{array}{l}\text { Long-lead items are not identified and defined during design for } \\
\text { early procurement }\end{array}$ & 3.45 & 29 & 5 & 0.001 * \\
\hline N4.5 & $\begin{array}{l}\text { Shop drawing process is not merged into design as contractors and } \\
\text { manufacturer/supplier cannot document construction intent }\end{array}$ & 3.82 & 12 & 2 & $0.000 *$ \\
\hline N4.6 & Prefabrication of some systems cannot start as design is not fixed & 3.97 & 4 & 1 & 0.000 * \\
\hline \multicolumn{6}{|c|}{ Agency permit/Bidding/Preconstruction $(\alpha=0.748)$} \\
\hline N5.1 & $\begin{array}{l}\text { Architect and engineers only pass two-dimensional (2D) drawings } \\
\text { or incomplete three-dimensional (3D) BIM models to contractors } \\
\text { and manufacturer/supplier }\end{array}$ & 3.88 & 10 & 1 & 0.000 * \\
\hline N5.2 & $\begin{array}{c}\text { General contractor has to re-build BIM model based on insufficient } \\
\text { documents from designers }\end{array}$ & 3.79 & 13 & 2 & 0.000 * \\
\hline N5.3 & $\begin{array}{l}\text { General contractor extends 2D drawings (without BIM) from } \\
\text { designers to guide construction }\end{array}$ & 3.79 & 13 & 2 & 0.000 * \\
\hline
\end{tabular}


Table 3. Cont.

\begin{tabular}{|c|c|c|c|c|c|}
\hline Code & NVA Activities & Mean & $\begin{array}{l}\text { Overall } \\
\text { Rank }\end{array}$ & $\begin{array}{l}\text { Internal } \\
\text { Rank }\end{array}$ & $p$-Value \\
\hline \multicolumn{6}{|c|}{ Construction (including Manufacture) $(\alpha=0.787)$} \\
\hline N6.1 & Owner and designers enable changes during construction & 3.93 & 5 & 1 & 0.000 * \\
\hline N6.2 & $\begin{array}{l}\text { Architect and engineers need long time to respond to contractors' } \\
\text { RFIs as their design models cannot directly guide site work }\end{array}$ & 3.70 & 19 & 4 & $0.000 *$ \\
\hline N6.3 & Architect and engineers do not update their design models & 3.60 & 21 & 5 & 0.000 * \\
\hline N6.4 & $\begin{array}{c}\text { Contractors and manufacturer/supplier have excessive RFIs } \\
\text { and paperwork }\end{array}$ & 3.77 & 15 & 2 & 0.000 * \\
\hline N6.5 & $\begin{array}{l}\text { General contractor communicates insufficiently with other } \\
\text { key stakeholders }\end{array}$ & 3.36 & 34 & 8 & $0.005^{*}$ \\
\hline N6.6 & $\begin{array}{l}\text { Low proportion of building components in superstructure and } \\
\text { fitting out using off-site manufacture }\end{array}$ & 3.40 & 32 & 7 & 0.000 * \\
\hline N6.7 & Congestion and many interfaces on site & 3.73 & 17 & 3 & 0.000 * \\
\hline N6.8 & $\begin{array}{l}\text { Incomplete 2D drawings or 3D BIM models for trade contractors } \\
\text { and manufacturer/supplier }\end{array}$ & 3.49 & 27 & 6 & 0.000 * \\
\hline \multicolumn{6}{|c|}{ Handover/Closeout/Operations and maintenance $(\alpha=0.772)$} \\
\hline N7.1 & $\begin{array}{l}\text { As-built BIM models are not handed to facility manager who uses } \\
\text { insufficient levels of detail } 2 \mathrm{D} \text { as-built drawings }\end{array}$ & 3.52 & 23 & 1 & $0.000 *$ \\
\hline N7.2 & $\begin{array}{c}\text { Many disputes/claims/litigations between general contractor and } \\
\text { owner and designers }\end{array}$ & 3.37 & 33 & 2 & 0.001 * \\
\hline N7.3 & $\begin{array}{l}\text { Facility manager does not have sufficient BIM-based design and } \\
\text { construction information for operations and maintenance }\end{array}$ & 3.33 & 35 & 3 & 0.008 * \\
\hline
\end{tabular}

* The one-sample $t$-test result was significant at the 0.05 level (two-tailed). \# The NVA activity was not significantly agreed upon by the respondents as a critical NVA activity.

The NVA activities were ranked according to their mean scores which ranged from 2.81 to 4.21 . To test whether each NVA activity was significantly agreed upon by the professionals in the Singapore construction industry, the one-sample $t$-test was conducted. The activities that obtained mean scores above 3.00 and $p$-values below 0.05 were deemed as critical NVA activities. The results in Table 3 indicated that 38 out of the 44 activities were widely agreed upon NVA activities in the current industry practices. The top 10 critical NVA activities are discussed below.

Three NVA activities in the design development phase occupied the top three overall rankings, namely, "lack of involvement by general contractor and key trade contractors to contribute site knowledge (not appointed)" (N3.5, ranked first), "coordination of building systems is deferred until construction phase due to unavailable trade contractor input until then" (N3.4, ranked second), and "lack of involvement by manufacturer/supplier (not appointed) to contribute knowledge of material selection, transportation, site erection, and so on" (N3.7, ranked third). This result substantiated the argument by Gao and Fischer [32] that the participation of the contractors and manufacturers/suppliers in the detailed design stage is essential for a building project that implements BIM. Without their early involvement, detailed off-site production and on-site activities cannot be well coordinated in the virtual design environment before actual construction commences [29]. This can be attributed to insufficient construction knowledge and experience of upfront design consultants to support detailed design coordination [65]. Consequently, the problems that traditionally would happen on site remained unsolved until the construction stage where such problems would inevitably occur. In the Singapore context, the professionals participating in the post-survey interviews reported that, even in the construction phase, there was generally insufficient collaboration between the design consultants and the contractors. The communication between the designers and site managers was weak. Moreover, another highly ranked NVA activity in this phase was "lack of involvement by facility manager (not appointed) to contribute operation and maintenance knowledge" (N3.8, ranked sixth), suggesting that the operations and maintenance team should also be appointed and involved no later than the design development phase [35]. The post-survey interviewees also highlighted that, without the downstream parties' contribution, design modeling could not be fixed early to guide site work. Their proactive participation upfront would significantly improve the flow of information throughout the design, construction, and operations and maintenance phases, and enrich the operations and maintenance information which was often unavailable in the current industry practices in Singapore. 
The fourth-ranked NVA activity was "prefabrication of some systems cannot start as design is not fixed" (N4.6) in the construction documentation phase, implying that, in the current project delivery, design was usually not fixed even after the design stage. Consequently, off-site production work could not proactively start to make room for enhancing the efficiency of performing construction activities. The incompletion of the design was not only due to the unavailable contractor input, but also due to unclear owner conception from the beginning which would affect the design consultants' understanding of the owner's brief. In the post-survey interviews, the professionals reported that, in Singapore, many consultants would not start on design modeling until the design was more or less confirmed by the owner. As a result, frequent change orders would be enabled by the owner and design consultants in the later stages of the project, significantly affecting construction efficiencies. Thus, the NVA activity "owner and designers enable changes during construction" (N6.1) in the construction phase received the fifth highest overall rating.

The sixth most agreement was also obtained by three NVA activities in the schematic design phase, including "lack of involvement by general contractor and key trade contractors to contribute site knowledge (not appointed)" (N2.4), "lack of involvement by manufacturer/supplier (not appointed) to contribute fabrication knowledge" (N2.5), and "lack of involvement by facility manager (not appointed) to contribute operation and maintenance knowledge" (N2.6). This result echoed the findings of El Asmar et al. [66] and Chan et al. [39] that, to change to fully implement BIM, the project should even engage the downstream parities from the early design stage. Although their proactive involvement would be most important in the design development phase when large numbers of construction details are required, the participation even earlier would have a larger impact on the finalization of project targets and metrics, as well as key deign parameters [29].

Another highly ranked NVA activity was "architect and engineers only pass two-dimensional (2D) drawings or incomplete three-dimensional (3D) BIM models to contractors and manufacturer/supplier" (N5.1) in the agency permit, bidding, and preconstruction phase. According to the experts participating in the post-survey interviews, the design consultants tended to overemphasize the regulatory BIM submissions, and their design models were not accurate enough to be used during construction. Additionally, the design consultants were usually not required by the owner and were unwilling to share their models with the contractors who would use extra time and manpower to re-build the design models $[18,67]$. Moreover, the design models may be of poor quality, and sharing such models may expose the consultants to liability issues [29,47]).

The internal rankings within each project phase were discussed. Apart from the top 10 critical NVA activities that were distributed from the schematic design phase to the construction phase, "no reward/risk sharing arrangements among major stakeholders are set by owner" (N1.2) and "as-built BIM models are not handed to facility manager who use insufficient levels of detail 2D as-built drawings" (N7.1) received the highest ratings in their respective phases. Reward and risk sharing arrangements in the project team from the beginning ensure that team members work in a best-for-project manner and build trust-based collaboration through project completion [22,30]. Once they are in the same boat, their corporate benefits are subject to this project's success. Moreover, using BIM in the operations and maintenance phase also drew much attention in previous studies [16,68], but the experts participating in the post-survey interviews found that BIM data were currently less relevant for facility management in Singapore.

Meanwhile, out of the 44 NVA activities, the remaining six had either mean scores below 3.00 or $p$-values above 0.05 , indicating that such activities did not obtain wide agreement of being NVA from the local BIM experts, despite their occasional occurrence in Singapore. These activities included (1) "lack of involvement by government agency" and "owner resists using BIM in the whole project" in the conceptualization phase, (2) "lack of involvement by government agency", "architect does not share its complete model with engineers", and "architect and engineers do not submit their schematic design models for regulatory approvals" in the schematic design phase, and (3) "lack of involvement by government agency" in the design development phase. 
The post-survey interviewees reported that the Singapore government is proactive in BIM implementation, such as mandating BIM e-submissions and issuing the most BIM standards and guides in Asia to specify BIM uses [12]; thus, "lack of involvement by government agency" was not significantly agreed upon. In addition, even if the owner may have a cost-beneficial thinking with no experience in implementing BIM [10,18], the experts involved in the post-survey interviews highlighted that BIM implementation is considered definitely beneficial to the owner in the long-term $[39,69]$ who is urged to be proactive in using BIM [70]. Thus, "owner resists using BIM in the whole project" was contradicted by the local circumstances. Moreover, in the post-survey interviews, the experts stated that the architect usually shared 2D documents with the engineers because the latter tended to be accustomed to the traditional way of designing, and that the architect would share its design model if the engineers were using compatible BIM tools in the design. Thus, "architect does not share its complete model with engineers" was not deemed critical. Furthermore, the government's strict review process on building plans submitted in BIM format made it unlikely that the "architect and engineers do not submit their schematic design models for regulatory approvals" would happen before the project could proceed.

\subsubsection{NVA Activities Comparison by Project Stakeholders}

Based on the BCA financial grades in Table 2, this study categorized the responding organizations into two groups: non-construction organizations upfront and construction firms. Since the only facility management firm also had a financial grade of L6, the numbers of the organizations in the non-construction group and construction group were 36 and 37. The reason for this categorizing was that the non-construction organizations were either policymakers or mandated to submit building plans in BIM format for regulatory approvals at earlier stages, and the construction firms were not or less affected by this policy. The BCA found that almost all the local consultants previously used BIM, but only large contractors were likely to use it [18].

To examine whether there were differences in the level of agreement mean scores of the 38 critical NVA activities between the two groups of responding organizations, the independent-samples $t$-test was performed. The $p$-values below 0.05 represent statistically significant differences in the mean scores. In addition, the Spearman rank correlation was conducted to test whether there was agreement in the rankings of the critical NVA activities between the two groups. A summary of the means and rankings, as well as the tests, is shown in Table 4.

The means of the 37 construction firms were found to be generally greater than those of the 36 non-construction organizations, revealing that the downstream stakeholders gave more weight to the critical NVA activities than the upfront participants. Compared with the upfront parties, most downstream parties realized the need for implementing BIM but were still reluctant to change their customized implementation practices [71]. Furthermore, the independent-samples $t$-test results indicated that the means of 10 critical NVA activities significantly differed between the two groups of organizations, which are analyzed according to their mean differences below.

Three NVA activities in the design development phase were the top three distinctive activities. Specifically, "architect does not share its complete model with engineers and contractors" (N3.3) had the largest difference in the mean score between the construction firms (mean $=3.73$ ) and the non-construction organizations (mean $=2.81$ ). In a building project in Singapore, the architect plays a principal role and its design is the starting point for using BIM. Without the architectural model, the other parties proceed in the traditional way, which is not the true spirit of BIM implementation [39]. Additionally, "construction model is not developed due to unwillingness of architect and engineers to share their BIM models" (N3.6) received a significantly higher mean score from the downstream parties (mean $=3.70)$ than from the upfront stakeholders (mean $=2.89$ ). The local government actively promotes BIM $[9,13]$. Compared with the upfront parties who simply changed from traditional drafting to BIM-based designing, the contractors became more burdened. The post-survey interviewees pointed out that the consultants' unwillingness to share posed duplicate efforts for the contractors to re-build 
the design models, which would increase construction cost [67], and that the unwillingness also created more decisions and human choices for the contractors to handle (such as to comply with various codes of practices), because the construction model currently creates too little automation and the site staff still tend to work with 2D drawings (such as to tie re-bars and erect formwork). In this case, BIM use was not a helping hand to construction work but was additional work to the contractors. In addition, the mean score of "insufficient design review and feedback by owner" (N3.1) in the construction firms $($ mean $=3.54)$ and the non-construction organizations (mean $=2.97)$ was the third distinctive activity. The experts participating in the post-survey interviews reported that the owner often enabled design changes during construction. Thus, if the design was not completely confirmed by the owner before actual construction started, the contractors may suffer from various changes (especially unexpected and late scope changes) in the later stages. While the consultants needed to update their design models and drawings, the downstream parties had to use much more manpower and time to modify their construction planning and day-to-day site work.

Table 4. Summary of level of agreement means and rankings of critical NVA activities.

\begin{tabular}{|c|c|c|c|c|c|c|c|c|}
\hline Phase & $\begin{array}{c}\text { NVA } \\
\text { Activity }\end{array}$ & \multicolumn{2}{|c|}{ Non-Construction $(N=36)$} & \multicolumn{2}{|c|}{ Construction $(N=37)$} & $p$-Value & \multicolumn{2}{|c|}{ Mean Difference } \\
\hline \multirow{3}{*}{ Conceptualization } & N1.1 & 3.53 & 18 & 3.49 & 33 & 0.865 & 0.04 & 33 \\
\hline & N1.3 & 3.17 & 34 & 3.65 & 28 & 0.074 & -0.48 & 10 \\
\hline & N1.4 & 3.78 & 9 & 3.68 & 27 & 0.697 & 0.10 & 25 \\
\hline \multirow{5}{*}{$\begin{array}{l}\text { Schematic } \\
\text { design }\end{array}$} & N2.1 & 3.56 & 17 & 3.46 & 34 & 0.720 & 0.10 & 27 \\
\hline & N2.3 & 3.25 & 32 & 3.73 & 22 & 0.076 & -0.48 & 11 \\
\hline & N2.4 & 3.83 & 6 & 4.00 & 11 & 0.512 & -0.17 & 24 \\
\hline & N2.5 & 3.81 & 7 & 4.03 & 8 & 0.400 & -0.22 & 21 \\
\hline & N2.6 & 3.81 & 7 & 4.03 & 8 & 0.405 & -0.22 & 21 \\
\hline \multirow{4}{*}{$\begin{array}{c}\text { Design } \\
\text { development }\end{array}$} & N3.1 & 2.97 & 36 & 3.54 & 30 & $0.016^{*}$ & -0.57 & 3 \\
\hline & N3.2 & 3.36 & 27 & 3.76 & 20 & 0.132 & -0.40 & 15 \\
\hline & N3.7 & 3.89 & 4 & 4.16 & 4 & 0.232 & -0.27 & 20 \\
\hline & N3.8 & 3.78 & 9 & 4.05 & 6 & 0.288 & -0.28 & 19 \\
\hline \multirow{6}{*}{$\begin{array}{l}\text { Construction } \\
\text { documentation }\end{array}$} & N4.1 & 3.58 & 16 & 3.92 & 14 & 0.140 & -0.34 & 17 \\
\hline & N4.2 & 3.17 & 34 & 3.73 & 22 & 0.031 * & -0.56 & 4 \\
\hline & N4.3 & 3.50 & 20 & 3.54 & 30 & 0.878 & -0.04 & 34 \\
\hline & N4.4 & 3.31 & 30 & 3.59 & 29 & 0.278 & -0.29 & 18 \\
\hline & N4.5 & 3.78 & 9 & 3.86 & 16 & 0.714 & -0.09 & 30 \\
\hline & N4.6 & 3.72 & 13 & 4.22 & 3 & $0.026^{*}$ & -0.49 & 9 \\
\hline \multirow{3}{*}{$\begin{array}{l}\text { Agency } \\
\text { permit/Bidding/ } \\
\text { Preconstruction }\end{array}$} & N5.1 & 3.67 & 14 & 4.08 & 5 & 0.089 & -0.41 & 14 \\
\hline & N5.2 & 3.53 & 18 & 4.05 & 6 & 0.030 * & -0.53 & 8 \\
\hline & N5.3 & 3.75 & 12 & 3.84 & 17 & 0.710 & -0.09 & 29 \\
\hline $\begin{array}{l}\text { Construction } \\
\text { (including } \\
\text { Manufacture) }\end{array}$ & N6.8 & 3.22 & 33 & 3.76 & 20 & $0.018^{*}$ & -0.53 & 6 \\
\hline \multirow{3}{*}{$\begin{array}{l}\text { Handover/Closeout/ } \\
\text { Operations and } \\
\text { maintenance }\end{array}$} & N7.1 & 3.50 & 20 & 3.54 & 30 & 0.858 & -0.04 & 34 \\
\hline & N7.2 & 3.36 & 27 & 3.38 & 36 & 0.933 & -0.02 & 38 \\
\hline & N7.3 & 3.28 & 31 & 3.38 & 36 & 0.679 & -0.10 & 26 \\
\hline Group mean & & 3.52 & & 3.80 & & & & \\
\hline $\begin{array}{l}\text { Spearman rank } \\
\text { correlation } \\
\text { coefficient }\end{array}$ & & 0.627 & & & & $0.000^{* *}$ & & \\
\hline
\end{tabular}

* The independent-samples $t$-test result was significant at the 0.05 level (two-tailed). ${ }^{* *}$ The Spearman rank correlation was significant at the 0.05 level (two-tailed). 
"Insufficient communication between architect and engineers" (N4.2) in the construction documentation phase was the fourth distinctive activity, with a mean score of 3.73 in the downstream parties and 3.17 in the upfront stakeholders. This was because the consultants might think their designs already met relevant requirements, and, in contrast, the contractors tended not to trust in the designs [14]. The post-survey interviewees emphasized that, actually, in many cases, the consultants' models were messy. For example, the green lines of the construction site were not at the same location in the architectural design and the structural design, some openings for the air-conditioning systems were not appropriately located, and columns were occasionally meters away from where they should be located. All these should have been corrected in the design stage. Thus, the contractors may expect that the consultants of different disciplines could have communicated and collaborated well with each other $[22,29,72]$. Because of the disordered conceptions from different consultants, the design of this project was not fixed by this stage. Consequently, the contractors, manufacturers, and suppliers could not commence off-site production, which would reduce construction efficiencies. Therefore, it was not strange that another critical NVA activity in this phase, "prefabrication of some systems cannot start as design is not fixed" $(\mathrm{N} 4.6)$, was ranked third (mean $=4.22)$ and 13th $($ mean $=3.72)$ in the downstream and upfront parties, respectively.

Furthermore, the experts involved in the post-survey interviews stated that, after winning the bid, the general contractor had to come back with the consultants to finalize their designs. In most cases, the MEP design models needed to be re-created. This explained why "general contractor has to re-build BIM model based on insufficient documents from designers" (N5.2) gained mean scores of 4.05 and 3.53 from the construction and non-construction organizations, respectively.

Nonetheless, due to poor coordination among different disciplines, design issues were delayed until the construction stage where the general contractor needed to communicate with each consultant, creating endless paperwork. The process of requesting and responding needed much manpower and time. Thus, "contractors and manufacturer/supplier have excessive RFIs and paperwork" (N6.4) exerted more agreement from the construction firms (mean $=4.03$ ) than from the non-construction organizations (mean $=3.50$ ). In addition, another three critical NVA activities in the construction phase also differed between the two groups of organizations. Because of potential liabilities, the consultants may not fully respond to the contractors' requests and, instead, might transform such issues to other consultants, again delaying the resolution of the issues [29,47]. This is also very common in the Singapore construction industry. Thus, "architect and engineers need long time to respond to contractors' RFIs as their design models cannot directly guide site work" (N6.2) obtained a significantly higher mean score in the downstream parties (mean $=3.97$ ) than in the upfront stakeholders (mean $=3.42$ ). Moreover, the mean score of "incomplete 2D drawings or 3D BIM models for trade contractors and manufacturer/supplier" (N6.8) was also much higher in the downstream parties $($ mean $=3.76)$ than in the upfront stakeholders $($ mean $=3.22)$. As the consultants need a long time to respond, the general contractor cannot fix the coordination of the designs in a short time. The professionals involved in the post-survey interviews found that, while the schedule was tight, the trade contractors had to proceed with whatever they had on hand; in this case, they could not wait for fully coordinated construction plans and could only get incomplete design models or drawings from the general contractor. Another distinctive NVA activity in this phase was "congestion and many interfaces on site" (N6.7), receiving a much higher mean score in the construction firms (mean $=3.95)$ than in the upfront stakeholders (mean $=3.50$ ). The post-survey interviewees explained that, during the process of finalizing the designs, there was a lack of communication between the contractors' in-house modelers and detailers and their site engineers. This created difficulties in arranging workspaces for the workers of different trades on site.

Despite the statistically significant differences in the means of the 10 critical NVA activities, the Spearman rank correlation coefficient of 0.627 with a $p$-value of 0.000 indicated significant agreement on the critical NVA activity rankings between the non-construction organizations upfront and the construction firms. This result was reasonable because both the upfront and downstream parties need 
to work collaboratively to efficiently implement BIM in this building project, such as staying in close communication and exchanging data of different disciplines [22,30,62].

\subsection{Resulting Wastes}

The 13 wastes not only serve as the effects of the critical NVA BIM implementation activities, but also bridge the NVA activities and the negative or slow productivity growth. While the previous section investigated which NVA activities would create wastes, this section investigates the critical wastes rather than all the wastes as a whole in the BIM-based project delivery process to understand a key part of the sources of the suboptimal productivity.

As shown in Table 5, the mean scores of frequency of occurrence and impact on productivity ranged from 2.68 to 3.89 and from 2.77 to 3.66 , respectively. The largest and smallest scores belonged to W02 and W13 for frequency of occurrence, as well as W03 and W09 for impact on productivity. Thus, none of the 13 wastes had a very high frequency of occurrence and a very low impact on productivity, and vice versa. The WC mean scores of the wastes were calculated and ranked (see Table 5). The top five critical wastes are discussed. Reworks/abortive works (W03) obtained the highest criticality (mean $=3.60$ ) to productivity performance, indicating that building projects in Singapore suffered from numerous abortive works [40]. This result echoed the post-survey interviewees who reported that abortive works occurred throughout the construction phase and influenced many trades on site. Trade contactors rarely used BIM [18] and usually arranged their construction activities ahead of time which may not be planned, updated, and reflected in the design models due to the lack of communication with the in-house BIM coordinators. Consequently, clashes were frequently detected during the construction stage and created abortive works, needing extra time and manpower to re-design, re-do, or repair the works.

Table 5. Mean and ranking of resulting wastes.

\begin{tabular}{|c|c|c|c|c|c|c|c|}
\hline \multirow{2}{*}{ Code } & \multirow{2}{*}{ Resulting Waste } & \multicolumn{2}{|c|}{$\begin{array}{c}\text { Frequency of } \\
\text { Occurrence }\end{array}$} & \multicolumn{2}{|c|}{ Impact on Productivity } & \multicolumn{2}{|c|}{ Waste Criticality } \\
\hline & & Mean & Rank & Mean & Rank & Mean & Rank \\
\hline W01 & Defects & 3.71 & 2 & 3.34 & 6 & 3.49 & 4 \\
\hline W02 & Requests for information & 3.89 & 1 & 3.29 & 7 & 3.53 & 2 \\
\hline W03 & Reworks/abortive works & 3.62 & 3 & 3.66 & 1 & 3.60 & 1 \\
\hline W04 & Waiting/idle time & 3.56 & 5 & 3.47 & 4 & 3.48 & 5 \\
\hline W05 & Change orders & 3.58 & 4 & 3.41 & 5 & 3.46 & 7 \\
\hline W06 & Activity delays & 3.51 & 7 & 3.48 & 3 & 3.47 & 6 \\
\hline W07 & Overproduction/reproduction & 3.19 & 8 & 3.05 & 8 & 3.10 & 8 \\
\hline W08 & Transporting/handling materials & 3.05 & 10 & 2.97 & 10 & 2.98 & 10 \\
\hline W09 & Unnecessary inventory & 2.99 & 12 & 2.77 & 13 & 2.83 & 12 \\
\hline W10 & Excess processing beyond standard & 3.08 & 9 & 2.95 & 11 & 2.99 & 9 \\
\hline W11 & $\begin{array}{l}\text { Unnecessary movement of people } \\
\text { and equipment }\end{array}$ & 3.04 & 11 & 2.90 & 12 & 2.94 & 11 \\
\hline W12 & $\begin{array}{c}\text { Design deficiencies (errors, } \\
\text { omissions, additions) }\end{array}$ & 3.53 & 6 & 3.53 & 2 & 3.51 & 3 \\
\hline W13 & Safety issues (injuries) & 2.68 & 13 & 3.05 & 9 & 2.81 & 13 \\
\hline
\end{tabular}

RFIs (W02) were ranked second (mean $=3.53$ ), suggesting that the productivity performance of building projects was seriously affected by the contractors' frequent enquiries and the design consultants' clarifications. In the post-survey interviews, the experts found that, in building projects in Singapore, plenty of time and manpower are wasted in paperwork. Since different consultants' design models are not well coordinated, the design issues are postponed until the construction stage where the contractors very often ask for clarifications or confirmations of verbal instructions. This process of requesting and responding wastes huge efforts and affects project progress. Nevertheless, the consultants may be wary of providing early and incomplete information to the contractors because the downstream parties that suffered from incorrect information may claim against the information providers [47]. An experienced interviewee reported that this occurred frequently in most design consultants in Singapore. Without knowing where the consultants were targeted, the contractors could 
not effectively plan. Similarly, the downstream parties, even if participating in the design stage, may be wary of providing advice that might involve them in design issues [29].

Design deficiencies (errors, omissions, additions) (W12) occupied the third position (mean $=3.51$ ). This result implied that the design consultants rarely collaborate with the downstream parities in the design stage [39]. This result substantiated the finding of Nikakhtar et al. [28] that a productive delivery should prevent construction deficiencies from being made through mistake-proofing in the planning stage. Because of the unclear owner conception and poorly coordinated design models, design errors and changes are not uncommon in the later stages [73]. The post-survey interviewees highlighted that the owner often had new conceptions during construction and added that deficiencies frequently occurred and large numbers of man-days were wasted on correcting the errors and dealing with the changes and their lifecycle implications. Consequently, the construction activities prone to errors could not be identified in time, delaying construction progress.

Defects (W01) were ranked fourth (mean $=3.49$ ), indicating that defective components were often produced in the construction phase, seriously affecting productivity performance. As the most obvious waste, every defective item would require reworks, repairs, or replacement, as well as creating paperwork, which would consume extra manpower, materials, facilities, and time.

Another highly ranked waste was waiting/idle time (W04, mean $=3.48)$, suggesting that the field personnel often consumed much time waiting for the design consultants' instructions and confirmations, the suppliers' materials supply, and so on. The post-survey interviewees also highlighted that, in the Singapore context, due to poor planning and coordination among different trades on site, the construction activities were frequently suspended, and the staff were idle on site until receiving further responses.

\subsection{Management Strategies to Mitigate NVA BIM Implementation Activities and Wastes}

Although BIM implementation is mandated, it is not a mainstream activity in Singapore. The above analysis and discussion provide a clear indication that specific management strategies can be drawn to mitigate the top-ranked NVA BIM implementation activities and, thus, reduce their resulting wastes in building projects. These strategies include the following:

1. Establishing standard contract. Although the BIM Particular Conditions contract was drafted to guide the Singapore construction industry to address the procedures of handling digital data, roles and responsibilities, intellectual property rights, each party's extent of reliance on 3D models, and contractual partnerships [74], the main form of the contract is still based on traditionally adversarial relationships. For example, design consultants and contractors have to create different models repeatedly. Thus, an updated version should be developed and established as the standard contract to incorporate BIM work processes into the contractual framework in Singapore. In a building project, this contract should be agreed upon by the owner and key designers and contractors, which enables the team to work collaboratively and share data openly $[29,30]$. In the post-survey interviews, the experts also highlighted that standard data exchange should be set by the local government, and that, without solid contracts, it would be hard to promote BIM implementation.

2. Clear owner conception. The post-survey interviewees found that it is common in Singapore that, as the project proceeds, the design consultants do not clearly know what the owner wants and how to complete the design. Thus, the owner should have clear conceptions and set clear requirements at the beginning (N6.1). Otherwise, unexpected and late scope changes would be costly in the later stages.

3. Involving key downstream participants early. The survey respondents cited NVA BIM implementation activities related to the lack of involvement by primary downstream parties in the design stage (N2.4-N2.6, N3.5, and N3.7-N3.8) as their top NVA activities. The post-survey interviewees advocated that successful BIM implementation needs the entire team, ranging from the owner to key contractors and manufacturer/supplier, to participate from early design [22]. 
They added that BIM implementation would be more efficient if all the key parties are co-located at one place. Indeed, lots of details need to be developed by specialist contractors. Without their knowledge and experience, the design cannot be coordinated fully and fixed early with sufficient constructability and fabrication (N3.4 and N4.6).

4. Offering project-wide and in-house training. Even if BIM is still new in the local market, the industry players have to embrace BIM-based project delivery. To build a robust team, the owner may provide training to the primary parties on how to use new software applications, reinvent workflow, assign responsibilities, and model construction process [75]. In particular, according to the post-survey interviewees, key specialty contractors usually use the traditional approach in design detailing and do not care about coordination with other trades on site. Thus, they need particular cultivation. The leadership team should spearhead design modeling and coordination for them. In addition, each party can provide constant in-house training to their employees to adapt to new policies, procedures, and operations [39].

5. Cultivating culture of sharing. Nothing is more important than a supporting culture. Thus, the standard contract should include provisions on the sharing of risks and rewards (N1.2). This makes the primary parties' corporate goals bound with the project's outcomes and avoids the downstream parties from working at risk upfront in a financial manner [33]. In this case, the team can openly share models to avoid duplicate efforts and costs in modeling. The professionals involved in the post-survey interviews observed that, due to potential liabilities, the team members do not fully exchange data (N5.1 and N7.1). For example, as the principal role in the Singapore context, the architect may change the design frequently without informing other designers and the contractors, hindering the creation of a composite design and construction model whereby all parties can work on it.

6. Highlighting short-term wins. Compared with adopting the traditional work practices, short-term performance gains of using BIM can convince the leadership team that BIM adds value to the project, can guarantee the sufficiency of resources, and can gain confidence in adapting to BIM-based delivery. In addition, those parties who successfully implement BIM gain a competitive edge to win bids in the future market.

\section{Conclusions and Recommendations}

This study examined the critical NVA BIM implementation activities in the current industry practices of delivering building projects in Singapore and investigated the criticality of the resulting wastes to productivity performance. A total of 44 NVA activities and 13 resulting wastes were identified in an earlier phase of this study. Through a questionnaire survey, presented in the Supplementary Materials, with 73 professionals and post-survey interviews with four BIM experts in Singapore, it was found that 38 out of the 44 activities were widely agreed upon as critical NVA activities, and the agreement of these NVA activities from the construction firms were generally greater than that from the upfront non-construction organizations. Despite the statistically significant differences in the mean scores of 10 NVA activities, overall, the two groups of organizations agreed on the rankings of the 38 critical NVA activities. In addition, the top five wastes with the highest criticalities were reworks/abortive works, RFIs, design deficiencies (errors, omissions, additions), defects, and waiting/idle time. These research findings were rarely examined in previous global studies [28], especially in the context of Singapore. Given that BIM implementation is mandated in Singapore, this study is the first to examine critical NVA BIM implementation activities in the current industry practices of delivering building projects in Singapore, and investigate the criticality of the wastes resulted from the NVA activities to productivity performance. Given resource constraints, the management must stay focused upon the most important areas rather than all key areas. The findings allow project leadership teams to prioritize manpower, materials, facilities, and time in the planning stage of their building projects to eliminate the wastes posed by the top-ranked NVA activities, thereby fostering competitiveness and sustainability. If everything is important, nothing is manageable. The strategies 
proposed in this study can be used as a basis for any project team to develop effective management toolkits for cutting down the critical NVA BIM implementation activities for enhanced productivity.

Despite the achievement of the research objectives, limitations still exist. Firstly, the NVA activities identified in this study may not be exhaustive or continue to hold true as time passes. Secondly, as the findings were analyzed and interpreted in the Singapore context, there may be geographical limitations on the identification of the critical NVA activities when implementing BIM in overseas building projects.

Nonetheless, the implication of this study is not limited to building projects in Singapore because of comparable industrial and cultural characteristics. Similar to Singapore, many other countries also tend to encourage, specify, or mandate BIM implementation in their building and construction projects by issuing relevant regulations and guidelines $[10,69,76]$, while the practitioners tend to be conservative to change $[9,14]$. In addition, other countries also only go a step further in including shared rewards and responsibilities in relational contracting to break out of the conservative industry culture. Thus, the critical NVA activities and their resulting wastes can, with minor adjustments, serve as an effective checklist for the global construction industry. Overseas projects can use the NVA activities identified in this study to prepare their customized lists of NVA BIM implementation activities according to their actual circumstances. Future research would investigate, through a few case studies, how typical building projects in Singapore change their BIM implementation practices so as to cut down critical NVA activities and, thus, eliminate the wastes for improving productivity, as well as achieving sustainability.

Supplementary Materials: The following is available online at http://www.mdpi.com/2071-1050/12/1/355/ s1: Questionnaire.

Author Contributions: Conceptualization, L.L. (Longhui Liao) and E.A.L.T.; methodology, L.L. (Longhui Liao); validation, L.L. (Linhui Li); formal analysis, L.L. (Longhui Liao), R.C., and L.L. (Linhui Li); investigation, L.L. (Longhui Liao) and E.A.L.T.; resources, L.L. (Longhui Liao) and E.A.L.T.; data curation, L.L. (Longhui Liao) and E.A.L.T.; writing—original draft preparation, L.L. (Longhui Liao); writing-review and editing, E.A.L.T., R.C., and L.L. (Linhui Li); visualization, L.L. (Linhui Li); supervision, E.A.L.T.; project administration, L.L. (Longhui Liao); funding acquisition, L.L. (Longhui Liao) and L.L. (Linhui Li). All authors have read and agreed to the published version of the manuscript.

Funding: This research was initially supported by the full-time research scholarship of the National University of Singapore and subsequently funded by the Guangdong Basic and Applied Basic Research Foundation (grant no. 2019A1515010719), the Shenzhen Philosophy and Social Sciences Planning project (grant no. SZ2019D016), and the Natural Science Foundation of Shenzhen University (grant no. 2019090).

Conflicts of Interest: The authors declare no conflicts of interest.

\section{References}

1. Wu, P.; Feng, Y.; Pienaar, J.; Xia, B. A review of benchmarking in carbon labelling schemes for building materials. J. Clean. Prod. 2015, 109, 108-117. [CrossRef]

2. Zuo, J.; Pullen, S.; Palmer, J.; Bennetts, H.; Chileshe, N.; Ma, T. Impacts of heat waves and corresponding measures: A review. J. Clean. Prod. 2015, 92, 1-12. [CrossRef]

3. Yang, X.; Hu, M.; Wu, J.; Zhao, B. Building-information-modeling enabled life cycle assessment, a case study on carbon footprint accounting for a residential building in China. J. Clean. Prod. 2018, 183, 729-743. [CrossRef]

4. Samari, M.; Esmaeilifar, R.; Shafiei, M.W.M. Green building: Strategic approach to sustainable economy. Int. J. Bus. Manag. 2014, 2, 198-202.

5. Nath, T.; Attarzadeh, M.; Tiong, R.L.; Chidambaram, C.; Yu, Z. Productivity improvement of precast shop drawings generation through BIM-based process re-engineering. Autom. Constr. 2015, 54, 54-68. [CrossRef]

6. Fan, S.L.; Lee, C.Y.; Chong, H.Y.; Skibniewski, M.J. A critical review of legal issues and solutions associated with building information modelling. Technol. Econ. Dev. Econ. 2018, 24, 2098-2130. [CrossRef]

7. Porwal, A.; Hewage, K.N. Building information modeling (BIM) partnering framework for public construction projects. Autom. Constr. 2013, 31, 204-214. [CrossRef] 
8. Sun, C.; Jiang, S.; Skibniewski, M.J.; Man, Q.; Shen, L. A literature review of the factors limiting the application of BIM in the construction industry. Technol. Econ. Dev. Econ. 2017, 23, 764-779. [CrossRef]

9. Juan, Y.K.; Lai, W.Y.; Shih, S.G. Building information modeling acceptance and readiness assessment in Taiwanese architectural firms. J. Civ. Eng. Manag. 2017, 23, 356-367. [CrossRef]

10. Yang, J.B.; Chou, H.Y. Mixed approach to government BIM implementation policy: An empirical study of Taiwan. J. Build. Eng. 2018, 20,337-343. [CrossRef]

11. ESC. Report of the Economic Strategies Committee; Economic Strategies Committee: Singapore, 2010.

12. Cheng, J.C.; Lu, Q. A review of the efforts and roles of the public sector for BIM adoption worldwide. J. Inf. Technol. Constr. 2015, 20, 442-478.

13. BCA. Reaching New Milestones with Design for Manufacturing and Assembly; Build Smart, Building and Construction Authority: Singapore, 2016.

14. Liao, L.; Teo, E.A.L.; Low, S.P. A project management framework for enhanced productivity performance using building information modelling. Constr. Econ. Build. 2017, 17, 1-26. [CrossRef]

15. SDOS. Yearbook of Statistics Singapore, 2018; Singapore Department of Statistics: Singapore, 2018.

16. Khosrowshahi, F.; Arayici, Y. Roadmap for implementation of BIM in the UK construction industry. Eng. Constr. Arch. Manag. 2012, 19, 610-635. [CrossRef]

17. Liao, L.; Teo, E.A.L. Organizational change perspective on people management in BIM implementation in building projects. J. Manag. Eng. 2018, 34, 04018008. [CrossRef]

18. Lam, S.W. The Singapore BIM Roadmap. In Proceedings of the Government BIM Symposium 2014, Singapore, 13 October 2014; Available online: http://bimsg.org/wp-content/uploads/2014/10/BIM-SYMPOSIUM_MRLAM-SIEW-WAH_Oct-13-v6.pdf (accessed on 15 June 2019).

19. Ohno, T. Toyota Production System: Beyond Large-Scale Production; Productivity Press: Portland, OR, USA, 1988.

20. Wang, J.; Wu, H.; Duan, H.; Zillante, G.; Zuo, J.; Yuan, H. Combining life cycle assessment and building information modelling to account for carbon emission of building demolition waste: A case study. J. Clean. Prod. 2018, 172, 3154-3166. [CrossRef]

21. NIBS. United States National Building Information Modeling Standard Version 1-Part 1: Overview, Principles, and Methodologies; National Institute of Building Sciences: Washington, DC, USA, 2007.

22. Alreshidi, E.; Mourshed, M.; Rezgui, Y. Factors for effective BIM governance. J. Build. Eng. 2017, 10, 89-101. [CrossRef]

23. Forsythe, P.; Sankaran, S.; Biesenthal, C. How far can BIM reduce information asymmetry in the Australian construction context? Proj. Manag. J. 2015, 46, 75-87. [CrossRef]

24. Liao, L.; Teo, E.A.L. Critical success factors for enhancing the building information modelling implementation in building projects in Singapore. J. Civ. Eng. Manag. 2017, 23, 1029-1044. [CrossRef]

25. Anumba, C.; Dubler, C.; Goodman, S.; Kasprzak, C.; Kreider, R.; Messner, J.; Saluja, C.; Zikic, N. BIM Project Execution Planning Guide-Version 2.0; Computer Integrated Construction Research Program, Pennsylvania State University: University Park, PA, USA, 2010.

26. Wu, P.; Low, S.P. Lean management and low carbon emissions in precast concrete factories in Singapore. J. Arch. Eng. 2012, 18, 176-186. [CrossRef]

27. Wu, P.; Low, S.P.; Jin, X. Identification of non-value adding (NVA) activities in precast concrete installation sites to achieve low-carbon installation. Resour. Conserv. Recycl. 2013, 81, 60-70. [CrossRef]

28. Nikakhtar, A.; Hosseini, A.A.; Wong, K.Y.; Zavichi, A. Application of lean construction principles to reduce construction process waste using computer simulation: A case study. Int. J. Ser. Oper. Manag. 2015, 20, 461-480. [CrossRef]

29. AIACC. Integrated Project Delivery: An Updated Working Definition; American Institute of Architects, California Council: Sacramento, CA, USA, 2014.

30. Piroozfar, P.; Farr, E.R.; Zadeh, A.H.; Inacio, S.T.; Kilgallon, S.; Jin, R. Facilitating Building Information Modelling (BIM) using Integrated Project Delivery (IPD): A UK perspective. J. Build. Eng. 2019, 26, 100907. [CrossRef]

31. Gibb, A.; Isack, F. Re-engineering through pre-assembly: Client expectations and drivers. Build. Res. Inf. 2003, 31, 146-160. [CrossRef]

32. Gao, J.; Fischer, M. Case Studies on the Implementation and Impacts of Virtual Design and Construction (VDC) in Finland; Center for Integrated Facility Engineering, Stanford University: Stanford, CA, USA, 2006. 
33. Ross, K.; Cartwright, P.; Novakovic, O. A Guide to Modern Methods of Construction; IHS BRE Press: Bucks, UK, 2006.

34. AIA; AIACC. Integrated Project Delivery: A Guide; American Institute of Architects: Sacramento, CA, USA, 2007.

35. Kunz, J.; Fischer, M. Virtual Design and Construction: Themes, Case Studies and Implementation Suggestions; Center for Integrated Facility Engineering, Stanford University: Stanford, CA, USA, 2012.

36. BCA. Singapore BIM Guide Version 2; Building and Construction Authority: Singapore, 2013.

37. McFarlane, A.; Stehle, J. DfMA: Engineering the Future. In Proceedings of the Council on Tall Buildings and Urban Habitat (CTBUH) 2014 Shanghai Conference, Shanghai, China, 16 September 2014; pp. 508-516.

38. Al-Sudairi, A.A. Evaluating the effect of construction process characteristics to the applicability of lean principles. Constr. Innov. Inf. Process Manag. 2007, 7, 99-121. [CrossRef]

39. Chan, D.W.; Olawumi, T.O.; Ho, A.M. Perceived benefits of and barriers to Building Information Modelling (BIM) implementation in construction: The case of Hong Kong. J. Build. Eng. 2019, 25, 100764. [CrossRef]

40. Hwang, B.G.; Zhao, X.; Yang, K.W. Effect of BIM on rework in construction projects in Singapore: Status quo, magnitude, impact, and strategies. J. Constr. Eng. Manag. 2019, 145, 04018125. [CrossRef]

41. Saieg, P.; Sotelino, E.D.; Nascimento, D.; Caiado, R.G.G. Interactions of building information modeling, lean and sustainability on the architectural, engineering and construction industry: A systematic review. J. Clean. Prod. 2018, 174, 788-806. [CrossRef]

42. Abdel-Razek, R.H.; Abd-Elshakour, H.; Abdel-Hamid, M. Labor productivity: Benchmarking and variability in Egyptian projects. Int. J. Proj. Manag. 2007, 25, 189-197. [CrossRef]

43. Alarcon, L. Lean Construction; A.A. Balkema: Rotterdam, The Netherlands, 1997.

44. Alwi, S.; Hampson, K.; Mohamed, S. Non Value-Adding Activities: A Comparative Study of Indonesian and Australian Construction Projects. In Proceedings of the 10th Annual Conference of the International Group for Lean Construction, Gramado, Brazil, 6-8 August 2002.

45. Arayici, Y.; Coates, P.; Koskela, L.; Kagioglou, M.; Usher, C.; O’Reilly, K. BIM adoption and implementation for architectural practices. Struct. Surv. 2011, 29, 7-25. [CrossRef]

46. Chua, D.K.; Yeoh, J.K. Understanding the Science of Virtual Design and Construction: What It Takes to Go Beyond Building Information Modelling. In Proceedings of the 2015 ASCE International Workshop on Computing in Civil Engineering, Austin, TX, USA, 21-23 June 2015; O’Brien, W.J., Ponticelli, S., Eds.; pp. 692-699.

47. Eastman, C.; Teicholz, P.; Sacks, R.; Liston, K. BIM Handbook: A Guide to Building Information Modeling for Owners, Managers, Designers, Engineers and Contractors, 2nd ed.; John Wiley \& Sons: New Jersey, NJ, USA, 2011.

48. Ekanayake, L.L.; Ofori, G. Building waste assessment score: Design-based tool. Build. Environ. 2004, 39, 851-861. [CrossRef]

49. Fan, S.L.; Skibniewski, M.J.; Hung, T.W. Effects of building information modeling during construction. J. Appl. Sci. Eng. 2014, 17, 157-166.

50. Formoso, C.T.; Isatto, E.L.; Hirota, E.H. Method for Waste Control in the Building Industry. In Proceedings of the 7th Annual Conference of the International Group for Lean Construction, University of California, Berkeley, CA, USA, 26-28 July 1999.

51. Forsberg, A.; Saukkoriipi, L. Measurement of Waste and Productivity in Relation to Lean Thinking. In Proceedings of the 15th Annual Conference of the International Group for Lean Construction, East Lansing, MI, USA, 18-20 July 2007.

52. Lee, S.H.; Diekmann, J.E.; Songer, A.D.; Brown, H. Identifying Waste: Applications of Construction Process Analysis. In Proceedings of the 7th Annual Conference of the International Group for Lean Construction, Berkeley, CA, USA, 26-28 July 1999.

53. Senaratne, S.; Wijesiri, D. Lean construction as a strategic option: Testing its suitability and acceptability in Sri Lanka. Lean Constr. J. 2008, 4, 34-48.

54. Teo, A.L.E.; Ofori, G.; Tjandra, I.K.; Kim, H. The Potential of BIM for Safety and Productivity. In Proceedings of the CIB W099 International Conference Achieving Sustainable Construction Health and Safety, Lund, Sweden, 2-3 June 2014.

55. Wong, P.F.; Salleh, H.; Rahim, F.A.M. Capability of building information modelling application in quantity surveying practice. J. Surv. Constr. Prop. 2014, 5, 1-13. 
56. Wu, P.; Low, S.P. Lean production, value chain and sustainability in precast concrete factory - a case study in Singapore. Lean Constr. J. 2011, 19-36.

57. Zhao, X.; Hwang, B.G.; Gao, Y. A fuzzy synthetic evaluation approach for risk assessment: A case of Singapore's green projects. J. Clean. Prod. 2016, 115, 203-213. [CrossRef]

58. Albaum, G. The Likert scale revisited: An alternative version. J. Mark. Res. Soc. 1997, 39, 331-348.

59. Hwang, B.G.; Zhu, L.; Tan, J.S.H. Identifying critical success factors for green business parks: Case study of Singapore. J. Manag. Eng. 2017, 33, 04017023. [CrossRef]

60. Miller, G.A. The magical number seven, plus or minus two: Some limits on our capacity for processing information. Psychol. Rev. 1956, 63, 81-97. [CrossRef]

61. Teo, E.A.L.; Chan, S.L.; Tan, P.H. Empirical investigation into factors affecting exporting construction services in SMEs in Singapore. J. Constr. Eng. Manag. 2007, 133, 582-591. [CrossRef]

62. Rezgui, Y.; Beach, T.; Rana, O. A governance approach for BIM management across lifecycle and supply chains using mixed-modes of information delivery. J. Civ. Eng. Manag. 2013, 19, 239-258. [CrossRef]

63. Nunnally, J.C. Psychometric Theory, 2nd ed.; McGraw-Hill: New York, NY, USA, 1978.

64. Robinson, J.P.; Shaver, P.R.; Wrightsman, L.S. (Eds.) Measures of Personality and Social Psychological Attitudes; Academic Press: San Diego, CA, USA, 1991.

65. Zhang, L.; Chu, Z.; He, Q.; Zhai, P. Investigating the constraints to buidling information modeling (BIM) applications for sustainable building projects: A case of China. Sustainability 2019, 11, 1896. [CrossRef]

66. El Asmar, M.; Hanna, A.S.; Loh, W.Y. Quantifying performance for the integrated project delivery system as compared to established delivery systems. J. Constr. Eng. Manag. 2013, 139, 04013012. [CrossRef]

67. Sattineni, A.; Mead, K. Coordination Guidelines for Virtual Design and Construction. In Proceedings of the 30th International Association for Automation and Robotics in Construction, Montreal, QC, Canada, 11-15 August 2013; pp. 1491-1499.

68. Aranda-Mena, G.; Crawford, J.; Chevez, A.; Froese, T. Building information modelling demystified: Does it make business sense to adopt BIM? Int. J. Manag. Proj. Bus. 2009, 2, 419-434. [CrossRef]

69. Smith, P. BIM implementation-Global strategies. Procedia Eng. 2014, 85, 482-492. [CrossRef]

70. Olawumi, T.O.; Chan, D.W.; Wong, J.K.; Chan, A.P. Barriers to the integration of BIM and sustainability practices in construction projects: A Delphi survey of international experts. J. Build. Eng. 2018, 20, 60-71. [CrossRef]

71. Zahrizan, Z.; Ali, N.M.; Haron, A.T.; Marshall-Ponting, A.; Hamid, Z.A. Exploring the adoption of Building Information Modelling (BIM) in the Malaysian construction industry: A qualitative approach. Int. J. Res. Eng. Technol. 2013, 2, 384-395.

72. Azhar, N.; Kang, Y.; Ahmad, I.U. Factors influencing integrated project delivery in publicly owned construction projects: An information modelling perspective. Procedia Eng. 2014, 77, 213-221. [CrossRef]

73. Lee, J.; Kim, J. BIM-based 4D simulation to improve module manufacturing productivity for sustainable building projects. Sustainability 2017, 9, 426. [CrossRef]

74. BCA. BIM Particular Conditions Version 2; Building and Construction Authority: Singapore, 2015.

75. Walker, D.; Lloyd-Walker, B. The future of the management of projects in the 2030s. Int. J. Manag. Proj. Bus. 2019, 12, 242-266. [CrossRef]

76. McAuley, B.; Hore, A.; West, R. BICP Global BIM Study-Lessons for Ireland's BIM Programme; Dublin Institute of Technology: Dublin, Ireland, 2017.

(C) 2020 by the authors. Licensee MDPI, Basel, Switzerland. This article is an open access article distributed under the terms and conditions of the Creative Commons Attribution (CC BY) license (http://creativecommons.org/licenses/by/4.0/). 